www.jmscr.igmpublication.org

Index Copernicus Value: 79.54

ISSN (e)-2347-176x ISSN (p) 2455-0450

crossref DOI: https://dx.doi.org/10.18535/jmscr/v7i5.131

Journal Of Medical Science And Clinical Research

IGM Publication

An Official Publication of IGM Publication

\title{
Comparative Assessment of External Ear: Morphometric Study and Sexual Dimorphism in Medical Student in SMS Medical College, Jaipur
}

\author{
Authors \\ Yadav Vishva Deepak ${ }^{1}$, Agarwal Chandra Kala ${ }^{2^{*}}$, Rajoria Sushil Raj ${ }^{3}$ \\ ${ }^{1,3}$ Postgraduate Student, ${ }^{2} \mathrm{Sr}$. Professor \\ Department of Anatomy, S.M.S. Medical College, Jaipur, Rajasthan, India \\ *Corresponding Author \\ Agarwal Chandra Kala \\ Sr. Professor, Department of Anatomy, S.M.S. Medical College, Jaipur, Rajasthan, India
}

\begin{abstract}
Introduction: Ear is not only an organ of hearing but it also maintains equilibrium. The knowledge about anatomy of ear is important for the plastic surgeons. Like fingerprints, the shape, size and orientation of each pinna play important role for identification of a person. Present study was planned to know the physical variations in ear dimensions and to know the role of ear lobule parameters in individual identification.

Materials and Methods: A cross sectional observational study was carried out at Department of Anatomy, SMS Medical College, Jaipur (Rajasthan) from March 2017 to February 2018. After taking permission from institutional ethics committee 258 medical students of 17-24 years and native of Rajasthan were included in the study. Individuals with altered external ear morphology by trauma, accidents or surgery were excluded. Various parameters of external ear like presence of free lobule, length and width of ear and lobule were measured and auricular and lobular indices were calculated. The data were statistically analysed using student ' $t$ ' test. P-value $<0.05$ was considered as statistically significant. Results: The free lobule was found in $84.2 \%$ subjects while ear lobule was attached in $15.8 \%$ subjects. The mean ear length of right and left ear in males were $6.12 \pm 0.40 \mathrm{~cm}, 6.03 \pm 0.54 \mathrm{~cm}$ respectively while in females it was $5.55 \pm 0.44 \mathrm{~cm}, 5.48 \pm 0.38 \mathrm{~cm}$ respectively. The mean ear width of right and left ear in males were $3.24 \pm 0.34 \mathrm{~cm}, 3.09 \pm 0.39 \mathrm{~cm}$ respectively while in females it was $2.80 \pm 0.37 \mathrm{~cm}, 2.65 \pm 0.36 \mathrm{~cm}$ respectively. The mean lobular length of right and left ear in males were $2.21 \pm 0.34 \mathrm{~cm}, 2.12 \pm 0.27 \mathrm{~cm}$ respectively while in females it was $2.17 \pm 0.30 \mathrm{~cm}, 2.07 \pm 0.23 \mathrm{~cm}$ respectively. The mean lobular width of right and left ear in males were $2.62 \pm 0.39 \mathrm{~cm}, 2.35 \pm 0.33 \mathrm{~cm}$ respectively while in females it was $2.44 \pm 0.42$ $\mathrm{cm}, 2.31 \pm 0.38 \mathrm{~cm}$ respectively.

Conclusion: Morphometric database of auricle is a potential suggestion for the diagnosis of congenital malformation, acquired deformities and syndromes as well as make a useful conclusion for purpose of forensic investigation of the crime.

Keywords: Medical students, External Ear, Morphometry, Sexual dimorphism.
\end{abstract}

\section{Introduction}

Study of the ear is known as Earology or Otomorphology. The physiognomy of the external ear is different from person to person like fingerprints and used for identification. Johann Casper Lavater first described 'Earology' while 
Haken Jorgensen, established a system of recording the morphology of the ear using ear dimensions and ear moulds. ${ }^{1}$

The length of adult vertical ear is approximately equal to the distance between the root of the helix and the lateral orbital rim at the level of the eye brow. The width of the ear is approximately $55 \%$ of its length. The rim of the helix protrudes $1-2 \mathrm{~cm}$ from the skull and there is an average protrusion angle of 21-25 degrees. ${ }^{2}$

The external human ear is divided into three parts: outer ear, middle ear and internal ear. The outer ear is further comprising of pinna (auricle) and external acoustic meatus. The pinna consists of the curving outer rim called the helix, the inner curved rim called the anti helix and opens into an ear canal. The hollow region in front of the ear canal is called the concha. In the floor of the concha lies the opening of external acoustic meatus which is anteriorly guarded by conical projection known as tragus. Tragus is separated from another bulge known as antitragus which lies in a notch. In lower part of ear pinna, a structure made up of a fibro fatty tissue known as 'lobule'. 3 The human earlobe is composed of adipose connective tissues and tough areolar tissue lacking the firmness and elasticityun like the rest of the auricle. There are two types of ear lobes: free type and attached type. Ear lobe attachment, position of ears and shape of the helix can used for the individual identification. ${ }^{4-5}$

Iannarelli was a pioneer in using ear features to identify peoples and he developed a forensic model in 1949. As the model-based approach is widely used in face recognition, it was surprising to discover that this approach had not yet been applied to ear-based identification, even though the ear contains more distinctive and robust features than facial characteristics, being unaffected by emotional expressions. ${ }^{6}$

Present study was carried out to identify the physical variations in ear dimensions, types of lobules with their proportions and to know the role of ear lobule parameters in individual identification.

\section{Material and Methods}

It was a cross sectional descriptive study which wascarried out in Department of Anatomy, SMS Medical College, Jaipur (Rajasthan) from March 2017 to February2018. Prior approval from institutional ethics committee and head of department was obtained and 258 medical students (equal no of both sexes) aged 17-24 years and native of Rajasthan were recruited in the study after taking informed written consent. Individuals with altered external ear morphology by trauma, accidents or surgery were excluded. Various parameters of external ear like type of ear lobule, length and width of external ear, length and width of lobule were measured, auricular and lobular indices were calculated. All the measurements of the subject were obtained by photography without touching him or her by any means. After taking the photograph, suitable size and editing of the image was executed with the Adobe Photoshop software (version 7.0). The data collected were entered in Microsoft Excel 2010 Spreadsheets and statistically analysed using student ' $t$ ' test. P-value $<0.05$ was considered as statistically significant.

\section{Results}

In the present study, 258 medical students (129 males and 129 females) were recruited. The free lobule was found in $117(84.2 \%)$ subjects while attached lobule was found in $41(15.8 \%)$ subjects. The mean length of right ear in males and females were $6.12 \pm 0.40 \mathrm{~cm}, 5.55 \pm 0.44 \mathrm{~cm}$ respectively while mean length of left ear were $6.03 \pm 0.54 \mathrm{~cm}$, $5.48 \pm 0.38 \mathrm{~cm}$ respectively. The gender difference between mean length was statistically significant for both ears (P-value < 0.001). The mean width of right ear in males and females were $3.24 \pm 0.34$ $\mathrm{cm}, 2.80 \pm 0.37 \mathrm{~cm}$ respectively while mean width of left ear were $3.09 \pm 0.39 \mathrm{~cm}, 2.65 \pm 0.36 \mathrm{~cm}$ respectively. The gender difference between mean width was also statistically significant for both ears (P-value < 0.001) (Table-1).

The mean lobular length of right side in males and females were $2.21 \pm 0.34 \mathrm{~cm}, \quad 2.17 \pm 0.30 \mathrm{~cm}$ respectively while mean lobular length of left side 
were $2.12 \pm 0.27 \mathrm{~cm}, 2.07 \pm 0.23 \mathrm{~cm}$ respectively. For both ear lobules, the gender difference between mean lobular length was statistically not significant (P-value > 0.05). The mean lobular width of right side in males and females were $2.62 \pm 0.39 \mathrm{~cm}, 2.44 \pm 0.42 \mathrm{~cm}$ respectively while on left side these were $2.35 \pm 0.33 \mathrm{~cm}, 2.31 \pm 0.38 \mathrm{~cm}$ respectively. The gender difference between mean lobular width was statistically significant for right side (P-value $<0.001)$ while statistically not significant for left side (P-value > 0.05) (Table-1). The auricular index [(auricular width/auricular length) $\mathrm{x} 100]$ and lobular index [(lobular width/lobular length)x100] were calculated for both sides. The mean auricular index of right ear in males and females were 50.39 $\pm 4.8,59.95 \pm 6.35$ respectively while on left side it was $55.03 \pm 4.82$, $45.17 \pm 5.35$ respectively. The gender difference between mean auricular index was statistically significant for both ears (P-value $<0.001)$. The mean lobular index of right side in males and females were $122.35 \pm 16.92, \quad 107.51 \pm 19.34$ respectively while on left side these were $106.15 \pm 15.59, \quad 109.3 \pm 18.6$ respectively. The gender difference between mean lobular index of right side was statistically significant (P-value < 0.001 ) but of left side was statistically not significant $(\mathrm{P}$-value $>0.05)$ (Table-1).

Table-1: Comparative analysis of ear parameters

\begin{tabular}{|l|c|c|c|c|}
\hline \multirow{2}{*}{ Parameter } & Side & $\begin{array}{c}\text { Male } \\
(\text { Mean } \pm \text { SD) }\end{array}$ & $\begin{array}{c}\text { Female } \\
(\text { Mean } \pm \text { SD) }\end{array}$ & P-value* \\
\hline \multirow{2}{*}{ Ear length (in cm) } & Right & $6.12 \pm 0.40$ & $5.55 \pm 0.44$ & $<0.001$ \\
\cline { 2 - 5 } & Left & $6.03 \pm 0.54$ & $5.48 \pm 0.38$ & $<0.001$ \\
\hline \multirow{2}{*}{ Ear width (in cm) } & Right & $3.24 \pm 0.34$ & $2.80 \pm 0.37$ & $<0.001$ \\
\cline { 2 - 5 } & Left & $3.09 \pm 0.39$ & $2.65 \pm 0.36$ & $<0.001$ \\
\hline \multirow{2}{*}{ Lobular length (in cm) } & Right & $2.21 \pm 0.34$ & $2.17 \pm 0.30$ & 0.319 \\
\cline { 2 - 5 } & Left & $2.12 \pm 0.27$ & $2.07 \pm 0.23$ & 0.112 \\
\hline \multirow{2}{*}{ Lobular width (in cm) } & Right & $2.62 \pm 0.39$ & $2.44 \pm 0.42$ & $<0.001$ \\
\cline { 2 - 5 } & Left & $2.35 \pm 0.33$ & $2.31 \pm 0.38$ & 0.369 \\
\hline \multirow{2}{*}{ Auricular Index } & Right & $50.39 \pm 4.8$ & $59.95 \pm 6.35$ & $<0.001$ \\
\cline { 2 - 5 } & Left & $55.03 \pm 4.82$ & $45.17 \pm 5.35$ & $<0.001$ \\
\hline \multirow{2}{*}{ Lobular Index } & Right & $122.35 \pm 16.92$ & $107.51 \pm 19.34$ & $<0.001$ \\
\cline { 2 - 5 } & Left & $106.15 \pm 15.59$ & $109.3 \pm 18.6$ & 0.143 \\
\hline \multirow{4}{*}{ Unpaired 't' test } & & & & \\
\hline
\end{tabular}

\section{Discussion}

Anthropometry is an important tool for examining any morphological structure. Ear is identifying part of face. Structure of ear is important to determine age and gender. ${ }^{7}$ Measurements for ear could be made on living people or on picture. ${ }^{8}$ Accurate knowledge of ear position, measurements and symmetry are important for reconstructive ear surgeries where opposite ear can't be used as template. Knowing relative values for face structures belonging to different race, age, ethnical group and gender are also important for surgery usage. ${ }^{9}$

In the present study attached lobule was found in $15.8 \%$ subjects. It was consistent with previous study by Chattopadhyay et al ${ }^{10}(18.7 \%)$ while contrary to other studies by Lai and Walsh ${ }^{11}$
(67.1\% among Japanese and 64.1\% in Chinese subjects). Frequency of free ear lobules observed by $\mathrm{Pal}^{12}$ in tribes of the Andaman Islands was $48.89 \%$ and by Dutta \& Gangulyin Brahmins was $63.92 \%$ while in this study it was $84.2 \%$.

Different morphometric measurements were determined from right and left ears with mean values. The mean length of right and left ear in male and females of present study (Table-1) were very close to previous studies by Bozkir et $\mathrm{al}^{13}$ (right ear male- $62.9 \pm 3.5 \mathrm{~mm}$, right ear female$59.7 \pm 3 \mathrm{~mm}$, left ear male- $63.1 \pm 3.6 \mathrm{~mm}$, left ear female- $59.1 \pm 2.9 \mathrm{~mm}$ ) while on higher side as compared to results observed by Eknem et $\mathrm{al}^{14}$ (mean ear height- 5. $60 \pm 0.56 \mathrm{~cm}$ ). Azaria et $\mathrm{al}^{15}$ studied on length of earlobe by age and sex conducted in Israel population. The sample size 
was 547 adults above the age of twenty years. The average length of right earlobe was $2.01 \pm 0.42$ cmand of left earlobe was $1.97 \mathrm{~cm} \pm 0.42 \mathrm{~cm}$. Eknem et $\mathrm{al}^{14}$ observed the mean lobular length $1.11 \pm 0.27 \mathrm{~cm}$. The results of the present study were slightly higher for both ears.

Brucker et $\mathrm{al}^{16}$ found in their study that males had $4.6 \%$ longer ears than the females. Sforza et $\mathrm{al}^{9}$ found that all the measurements of ear were significantly larger in males. Similar results were found in the present study where all the measurements of ear were larger in males. Shireen et $\mathrm{al}^{17}$ showed that all the parameters were significantly higher in the right ear in both females and males, it was statistically evidenced. All dimensions were found developed in males according to females on both sides. Present study concurs with above conclusion.

\section{Conclusion}

Ear parameters may be useful for deciding the sex and age of an individual whose identity is unknown, required to compare the pinna or auricle for growth assessment and development of an individual. In present study photographic method was used to measure the parameters of ear so the conclusions may be useful for purpose of forensic investigation of the crime.

\section{References}

1. Singhal J, Sharma N, Jain SK, Budhiraja V, Rastogi R, Garg R, Nafees H. A Study of Auricle Morphology for Identification in Indians. Ann. Int. Med. Den. Res. 2016;2(4):217-24.

2. Farkas LG. Anthropometry of normal and anomalous ears. Clin Plast Surg. 1978;(5): 401-412.

3. Gray's Anatomy. Churchill Livingstone Elsevier. $40^{\text {Th }}$ ed. Elsvier Ltd; 2008: 651652.

4. Steinberg A. Encyclopedia of Jewish Medical Ethics: a compilation of Jewish Law on all Topics of Medical Interest.
Jerusalem: Feldheim Publishers, ISBN 1583305920: 350.

5. Saul FP., Saul JM. Planes, trains and fireworks, in hard evidence: Case study in Forensic Anthropology (Ed. Steadman, DW). Englewood Cliffs, NJ: Prentice Hall., 2003:266-277.

6. Iannarelli AV. Forensic Identification Series: Ear Identification. Paramount: California., 1989.

7. Kalra D, Kalra A, Goel S. Anthrometric measurements of external ear: An in vivo study. Intern J Enhanced Res in Med Den Care. 2015;2:10-16.

8. Vinita M, Punnya A, Seema H, Alka K. Anthropometric study of the external ear and its applicability in sex identification: assessed in an Indian sample. Aust J Forensic Sci. 2013;45:431-444.

9. Sforza C, Grandi G, Binelli M, Tommasi DG, Rosati R. Age- and sex-related changes in the normal human ear. Forensic Sci Int. 2009;187:110.

10. Chattopadhyay PK. A note on the ear lobe attachment among the Jats and Ahirs. Acta Genet Basel. 1968;18:277-282.

11. Lai LY, Walsh RJ. Observations on ear lobe types. Acta Genet Stat Med. 1966. 16(3):250-7.

12. Pal A. Ear lobe attachment of the Onge. Hum Hered. 1970;20:650-653.

13. Bozkir MG, Karakas P, Yavuz M, Dere F. Morphometry of the external ear in our adult population. Aesthetic Plastic Surgery. 2006;30:81-85.

14. Ekanem AU, Garba SH, Musa TS, Dare ND. Anthropometric study of the pinna (Auricle) among adult Nigerians resident in Maiduguri metropolis. J Med Sci. 2010;10(6):176-180.

15. Azaria R, Adler N, Selfin R, Regev D, Hauben DJ. Morphometry of the adult human earlobe: A study of 547 subjects and clinical application. PlastReconstr Surg. 2003;111(7):2398-2402. 
16. Bruker MJ., Patel J, Sullivan PK. A morphometric study of the external ear: age and sex-related differences. Plast Reconstr surg. 2003; 112(2): 647-625.

17. Shireen S, Vrushali P, Karadkhelkar. Anthropometric measurements of Human External Ear. Journal of Evolution of medical And Dental Sciences. 2015;59(4):10333-10338. 